\title{
Defining Employee Benefits: A Managerial Perspective
}

\author{
Robert Klonoski \\ Associate Professor of Business \\ Mary Baldwin College \\ Staunton, VA 24401, United States \\ Email: reklonoski@gmail.com
}

Received: April 13, 2016 Accepted: April 25, 2016 Published: May 21, 2016

doi:10.5296/ijhrs.v6i2.9314 URL: http://dx.doi.org/10.5296/ijhrs.v6i2.9314

\begin{abstract}
"Benefits" are offered to employees because they promote job satisfaction and increase organizational commitment. They are generally defined as forms of indirect or non-wage compensation, conceptualizations that are principally useful for accounting and tax purposes. A definition of "benefits" from a managerial perspective can help to clarify how they can be used to achieve employee satisfaction and commitment. This article includes a brief history of benefits, an international comparison of their usage, and a review of their most widely accepted definitions. A new definition of employee benefits is proposed.
\end{abstract}

Keywords: Employee benefits, Managerial perspective, Employees commitment 


\section{Introduction}

Employee benefits have been defined by the Bureau of Labor Statistics as any form of indirect or non-cash compensation paid to an employee (BLS, 2008). In the United States, they may be required by law or regulation, as are employer contributions to Social Security or health care benefits, or they may be discretionary, such as contributions to retirement savings or paid time off. Organizations offer benefits to their employees because they promote job satisfaction and inspire worker loyalty, which, in turn, can lead to better financial performance (Chan, Gee \&Steiner, 2000; Rutigliano, 1986).

Modern work benefits such as health care and retirement began to take shape in Germany in the $19^{\text {th }}$ century as forms of social protections. They were adopted in the United States in stages - paid time off during the Industrial Revolution; retirement in the aftermath of the Civil War and again as part of the New Deal; healthcare during the Second World War, and more. In the United States, they reached the peak of their popularity in the 1980s, partly because of the preferential tax treatment for certain benefits, but also because of the aging and gender balancing of the workforce (Rhine, 1987).In more recent decades, however, the accessibility of benefits to American employees has begun to decline (Klonoski, 2015, p. 9). Since the 1980s, employee benefits have also changed in kind. Defined benefit plans have been replaced, for the most part, by defined contribution $(401 \mathrm{k})$ plans. Healthcare benefits have largely switched from managed care to consumer-directed programs. Absences from work are less frequently segmented into vacation, holidays and sick leave and are often packaged into a single inclusive "paid time off" bundle. Workers have become more individually responsible for their retirement and healthcare, and for managing their own time away from work.

While much has been written about the use and relevance of employee benefits to the organization, little has been done to define benefits from a management perspective. Many of the available definitions of employee benefits demonstrate what they are by way of example (American College Dictionary, 1947; BLS, 2006), or through the qualifications that make them tax deductible (Internal Revenue Service, 2016). This begs the question of how managers should conceive of benefits. Are they a tool for recruiting and retaining a labor force? A part of compensation? Or, forms of social protections that governments require businesses to provide?

\section{Benefits: Usage and Definitions}

\subsection{Types of Work Benefits}

In recent years, the Society for Human Resource Management (SHRM) has organized its overview of employee benefits in the United States into the following categories (SHRM, 2014):

- Preventive health and wellness, a category that includes wellness programs and resources for employees;

- Retirement savings and planning benefits, such as defined benefit or defined 


\section{Macrothink}

contribution retirement plans;

- Financial and compensation benefits such as free on-site parking, company-paid group life insurance, service anniversary awards, educational assistance, cell phone usage, and executive incentive plans;

- Leave benefits including paid time off for holidays, bereavement, jury duty (above that required by law), and, to a lesser extent, for vacations and for a combined category of illness, vacation and personal time termed "paid time off";

- Family-friendly benefits such as dependent care flexible spending accounts that allow employees to set aside pretax dollars that can later be used to reimburse them for dependent care expenses;

- Flexible working benefits which includes casual clothing days as well as telecommuting and flextime;

- Health care and welfare, a category that includes programs required by the Affordable Care Act, such as drug and mental health coverage, as well as those that are not required, such as dental insurance;

- Employee programs and services which includes a collection of conveniences and discounts such as free coffee, access to a vending machine and free or discounted uniforms;

- Professional and career development benefits such as professional memberships and development opportunities, as well as certification and recertification fee reimbursements;

- Housing and relocation benefits including lump sum relocation reimbursements as well as temporary relocation assistance; and,

- Business travel benefits, including reimbursements for cab fare or car mileage for travel to and from an airport as well as per diem reimbursements for meals.

The list of benefits reported by the SHRM is extensive. It includes items that may be accurately described as forms of indirect or non-cash compensation, but it also includes items that are employee conveniences or desirable job characteristics. While some employees may value an opportunity to dress casually or to have the option to set aside pre-tax wages toward retirement, etc., it may not be entirely accurate to use the term "indirect compensation" to describe these benefits. Still, programs and practices such as these can be useful in creating an atmosphere in which employees may be more engaged and motivated than they would be in an environment absent of these programs and practices. To understand how this collection of benefits grew to its current levels, it would be useful to briefly review how benefits came into the workplace.

\subsection{Historical Background}

Offering benefits to employees in the United States is a centuries-old practice, predating even 
the founding of the country. As early as the Roman Empire century, soldiers received pensions, and the fall of the Roman Empire may be, at least in part, related to the non-payment of these pensions (Clark, Craig \& Wilson, 2003, p. 1). The earliest employee benefits programs in North America were brought to the continent by the colonizing Europeans. For more than a century before the beginning of the Revolutionary War, British colonies in North America provided pensions for disabled soldiers and sailors (U.S. National Archives and Records Service, 1974). During and after the Revolutionary War (1775-1783), two more categories of pensions were granted to soldiers who had served inthe American military. They were awarded to those who had served for a minimum term of service, and to the widows of those who had been killed in service (U.S. National Archives and Records Service, 1974). In 1798, Congress established one of the nation's first healthcare benefits by creating a network of hospitals for the care of merchant seamen (National Institute of Health, 1798). These programs were greatly expanded in 1862 when Congress established the Union army pension plan (Pension Act of 1862). By 1900, approximately $21 \%$ of all white males in the United States who were aged 55 and over were receiving pension payments from the federal government based on their having served in the Union Army during the Civil War (Costa, 1998, p. 197).

Private sector employee benefits first began to take shape in Europe in the latter part of the 19th century. Otto von Bismarck, the first Chancellor of a newly united Germany, was pressed to develop social protections to placate the Socialists, who were beginning to gain political strength there. In 1883, he oversaw the establishment of "illness" insurance for workers. Under the program he proposed, the cost of medical care and wages for up to 13 weeks of absence from work would be split between employers and employees (Leichter, 1979, p. 121). He went on to launch programs for accident insurance (Holborn, 1969. pp. 291-293) and for pensions for those aged 70 and over (Hennock, 2007, p. 157).

In the United States, paid time off, which had been a province of the wealthy and leisure class during colonial times, gained popularity through the $19^{\text {th }}$ century and by 1850 people employed in "white collar" professions customarily received one week's paid vacation as a standard benefit (Aron, 1999, p. 47). Other benefits followed. In 1910, Montgomery Ward and Company became the first U.S. company to offer health insurance to all of its general employees as an employee benefit (Scofea, 1994, p. 4), but, in spite of its appeal, the benefit did not spread quickly. It would not become a standard part of an employment contract until political and economic events through the Great Depression and American participation in the Second World War would change the landscape of compensation and benefits.

Between 1933 and 1938, President Franklin D. Roosevelt proposed a series of domestic programs(Roosevelt Institute, n.d.) paralleling those developed in Germany a half-century earlier under the umbrella title of the "New Deal". In 1935, he signed the Social Security Act into law as part of this program, intending to encourage older workers to retire which would open jobs for younger (and less expensive) workers (Social Security Act, 1935). In 1930, $42 \%$ of males aged 65 and over had withdrawn from the workplace; by 1940, that number had increased to $50 \%$ (Costa, 1998, p. 50). 
While the Great Depression saw an abundant supply of labor and few jobs, this balance reversed during the Second World War. With much of the young male population taken by the armed forces and with factories needing to supply the war effort, wages began to climb as firms competed for the then scarce labor resources. Government intervention served to complicate this bidding process. Fearful of inflation and in reaction to the rising price of labor, Congress passed legislation to freeze wage and salary levels (The Stabilization Act of 1942). Exempted from these wage and price controls, however, were work benefits, and organizations began using them as an enticement for new recruits (Buchmueller and Monheit, 2009, p. 3).

Employee benefits in the United States realized their first gains in popularity as part of the New Deal program but they did not truly rise to widespread use until political forces positioned them as a solution to a labor shortage. Selected employee benefits also gained in popularity because of the favorable tax treatments they were receiving. They had become deductible expenses for employers but not considered part of an employee's gross income which was an added incentive for employees to seek them and for companies to offer them. Through the Second World War, benefits offerings grew very quickly. For example, in 1940, health insurance plans covered approximately 21 million workers in the United States; by 1950, that number had grown to 142 million (Blumenthal, 2006, p. 83). Employee benefits in America had suddenly become an expected and entrenched part of an employment contract.

Following the War, the National Labor Relations Board (NLRB) successfully sought to have employee benefits included in the definition of compensation in order to gain administrative jurisdiction over them in disputes between labor and management (National Labor Relations Act, as amended, 1951).Depending on the context in which they were being considered, several different definitions of employee benefits began to emerge.

\subsection{An International Perspective}

Adding to the difficulty with finding a conceptual definition of employee benefits is that internationally, views of "benefits" are very different than those in the United States. The International Accounting Standards Board (IASB) defines employee benefits as "all forms of consideration given by an entity in exchange for service rendered by employees or for the termination of employment." (IASB 19). The IASB definition does not seek to differentiate the two aspects of compensation, namely, wages and benefits; its purpose is to ensure that all forms of payments to employees are correctly accounted for as some form of compensation and so the definition is necessarily an inclusive one.

Among industrialized nations, employee benefits may differ both in degree and in kind, depending, in part, on the degree to which the benefits are regulated or subsidized by governments. Health care, for example, is generally administered through one of three types of programs: a national health service, a national health insurance system, or a multi-payer insurance system. In the first two, health care is paid through taxes and does not enter into the employment relationship. In countries using some form of the multi-payer system, employers and employees contribute to health care costs. Note, though, that few nations have "pure" versions of these programs. In a multi-payer nation like the United States, the government 
may subsidize health care costs for poor and/or elderly people. Other countries using some form of this system include France, Belgium, the Netherlands, Japan, Switzerland, and Germany. Where employers help to subsidize the cost of health insurance, the subsidy is an employee benefit, and is considered one of the most important of the benefits that employers offer (O'Brien, 2003, p. 5). The subsidy can be a voluntary one or one that is required by some form of government regulation.

As for paid time off, member states of the European Union require employers to afford their workers a minimum of four weeks of paid vacation per year; in the United States there is no national requirement that an organization afford its workers paid time off whether for vacation, illness, or any other purpose. Workers in the United Kingdom receive paid time off in line with that of the European Union members. In China, the minimum paid vacation time that organizations are required to give their full-time workers is five working days with an additional seven holidays; in India, the requirement is for twelve paid vacation days, but the number of holidays varies by region. Of the 160 nations surveyed by the International Labor Organization, only Kiribati, Laos and the United States have no law mandating paid time off for full-time workers (Ghosheh, 2013, p.18).

Like health care benefits, retirement benefits are provided by both employing organizations and government programs. Also like health care benefits, the balance between organizations and governments in providing for the retirement of employees varies widely from country to country. In most industrialized nations, retirement income is secured through a combination of government funded programs, government mandated savings programs, corporate contributions to retirement funds and individual savings. In the United Kingdom and the United States, for example, workers and organizations contribute to a social security program during their working years and are paid by the program in retirement. Nations like Malaysia and Singapore have mandatory savings plans for workers, which have been particularly effective in bringing the country's perceived retirement preparedness to superior levels. In nations like Canada where contributions to retirement savings are optional rather than mandatory, people tend to be less well prepared for retirement than in those countries where savings is mandatory (Moran, 2015).

As with health care, paid time off and retirement benefits, family and medical leave in the United States is less generous than in most other countries. Of the 167 countries whose maternity benefits were tracked by the International Labour Organization, only Papua New Guinea and the United States do not provide some form of cash benefits to women for a maternity leave (ILO, 2014, p. 16). In the United States, the federal legislation that addresses this topic is the Family and Medical Leave Act of 1993 (FMLA). Congress passed this legislation on the premise that "a direct correlation exists between stability in the family and productivity in the workplace" (FMLA, 1993, §825-101-c). By contrast, the International Labour Organization (ILO) proposed that maternity benefits be enacted by nation states in order "to ensure that women's work does not pose risks to the health of the woman and her child and to ensure that women's reproductive roles to not compromise their economic and employment security" (ILO, 2000, c183). The focus in the preamble to the United States legislation is divided between family stability and organizational productivity; the ILO 
convention is focused solely on the individual. In the United States, the most frequent use of the FMLA is for time off for medical care and is exercised by lower income workers who do not have access to paid time off (Lenhoff, 2004, p. 2).

In the United States, benefits are considered a part of compensation, something to be bargained for; in most other countries they are more heavily regulated and may be employed as forms of social protections (Ginneken, 2013, pp. 71-72). For example, the ILO (2012, Sec. $5 \& 6$ ) has as a guiding principal that it is a national responsibility to provide basic income security for new mothers and older persons, as well as health care services for citizens at a reasonable cost.

To some extent, employee benefits do serve societal purposes. Health care, retirement, and family and medical leave, for example, each have direct impacts on society. Some other types of benefits, like bonuses, subsidies, and employee discounts, more closely resemble compensation. National governments tend to more closely regulate those categories of benefits that serve some social purpose by, for example, subsidizing medical care for all or parts of the population, or for providing assistance to their elderly populations. Governments also use regulation to ensure social protections for their working populations by setting selected terms of employment, for example, requiring employers to offer paid time off or paid family and medical leave to their full time employees.

Because the presence of collective bargaining, the degree of government regulation and popular attitudes toward work vary from country to country, finding a universal definition of employee benefits becomes especially challenging. In the United States, employee benefits are something used to entice workers, build loyalty and increase job satisfaction (Chan, Gee \& Steiner, 2000; Rutigliano, 1986); however, employee benefits in most other countries are based on a concept of employee rights.

\subsection{Definitions of Benefits}

The piecemeal history of employee benefits in the United States makes finding a single definition for them difficult. Employee benefits, which have also been called work benefits or fringe benefits, have definitions that vary with the stakeholder - government, business, or labor - that is citing the term.

The agencies of the U.S. Government that are involved with labor have each published definitions of employee benefits. The Bureau of Labor Statistics depicts them as "nonwage compensation provided to employees" (BLS, 2008). The National Compensation Survey, conducted by the Bureau, aligns benefits into five categories: paid leave, supplementary pay, retirement, insurance, and legally required benefits such as Social Security, Medicare, Federal and State unemployment insurance taxes, and workers' compensation (BLS, 2015).In 2006, the Bureau of Labor Statistics added flextime to the list of benefits it measures (BLS, 2006, p. 2).

By including supplementary pay, such as premium pay for working on a weekend or holiday, the Bureau of Labor Statistics includes direct or cash compensation among the benefits that an employer may offer. This is consistent with the definition of benefits offered by the 
Internal Revenue Service, namely "a form of pay for the performance of services" (IRS, 2016) but inconsistent with the concept of benefits as being "nonwage."For tax purposes, benefits are forms of compensation that are includable in a person's gross income unless they fall within a specific list of qualified exclusions.

A popular definition of the term "fringe benefits" in America dates back to the Second World War when it made its first appearance in the American College Dictionary (1947). It was defined by way of examples: "any of various benefits, as free life or health insurance, paid holidays, a pension, etc., received by an employee in addition to regular pay". The use of the term "regular pay" suggests direct or cash compensation can be a form of benefit if it is not part of base compensation. More recently, the term "fringe benefits" can be found in the Dictionary of Cultural Literacy (2005), where it is depicted as - "a payment to a worker in addition to salary or wages. It may take the form of cash, goods, or services, and may include such items as health insurance, pension plans, and paid vacations."The emphasis on the word "payment" reinforces the concept that employee benefits are part of an employment contract, something to be negotiated in the process of hiring, renewing a term, or as part of ongoing performance and pay adjustments.

Managers tend to look at employee benefits differently than does the Government or Labor. According to the Business Dictionary (n.d.), employee benefits are a form of "indirect and non-cash compensation paid to an employee.'Black's Law Dictionary (n.d.) similarly characterizes them as "indirect, non-cash assistance given to an employee". Managers tend to differentiate between cash compensation, whether it is a salary, a bonus, or any other form of direct payment, and indirect payments, such as a subsidy, time off, or contributions to a health plan. Using the definition of employee benefits of the Bureau of Labor Statistics, supplemental pay is the only "benefit" that the employee receives as a direct cash payment, and it can take the form of overtime pay, bonuses, or shift differentials. Overtime pay is most frequently found in the production, construction, maintenance, and transportation industries; bonuses are typically found in the management, finance, and legal professions; and shift differentials are characteristic of the healthcare and personal care industries (Bishow, 2009). For a business, supplemental pay is a direct cost, a variable expense that can be directly assigned to a specific product or service; other benefits tend not to vary as much with the level of production as with the number of people employed and their respective base compensation.

\section{Table 1}

--- Insert Table 1 here ---

In sum, labor tends to define benefits as indirect forms of compensation, something given in addition to base compensation and not related to doing extra work, accomplishing certain goals, or working non-standard hours. A holiday bonus, for example, would be considered a benefit by labor, but a bonus for having exceeded production goals would more likely be 
described as pay. Employees consider benefits a part of their overall compensation, but when organizations are required by law to offer them, they may be thought of more as an entitlement than a negotiable part of compensation (Weatherington \& Tetrick, 2000, p.158).Other aspects of a job, including a casual dress code, flextime, or telecommuting options, are also considered to be valuable to employees even though they may not be a form of compensation (Ralston, 1989, pp. 371-372).

Managers tend to view benefits in a similar way, including some forms of compensation as well as certain job characteristics as benefits, but distinguishing between the direct and indirect costs of producing goods or providing services. By contrast, the BLS view includes the forms of indirect compensation contemplated by management and labor, and simply adds overtime, shift differentials and all other forms of bonuses to the mix, regardless of whether they are related to productivity.

The management view, namely, that work benefits include "indirect and non-cash compensation paid to an employee" provides a useful definition of the term in thatit recognizes that benefits are a category of compensation, but it places the locus of benefits expense in human resources rather than in production. For analysis, the BLS interpretation also provides a valuable resource, as numbers are reported for categories of benefits and can be studied separately or in combination. All of these definitions, however, are more useful for classifying benefits expenditures for accounting purposes than for demonstrating the ways in which they are conceptualized by management, or labor, or regulators.

\section{Analysis}

For management purposes, it may be helpful to group employee benefits according to their purposes and their effect on employees. To recap, some amount to forms of direct compensation, (e.g., contributions to retirement savings or per diem reimbursements for meals during business-related travel). Services like free coffee, or employee discounts are a form of indirect compensation. Other benefits address the conditions of work, such as flexible working hours or casual clothing days. Still others have important social purposes, such as retirement and medical benefits.

The operating definitions of "benefits" generally include the concept that benefits form an indirect compensation paid to an employee. Using this standard, flexible working hours or telecommuting would more accurately be described as job characteristics, albeit desirable ones for many employees, than as benefits. Similarly, casual clothing, which is becoming more the norm than the exception, is an aspect of corporate culture. To describe it as a form of indirect compensation would challenge even the most creative of accountants.

The categories of benefits outlined by the SHRM may be aligned into three principal categories. Note that benefits classified as affording some form of social protection may, in part or in full, involve a form of indirect compensation to the employee, and so may be listed in both columns. 


\section{Macrothink}

Table 2

---Insert Table 2 here ---

The benefits described above may be represented by a simple Venn diagram:

\section{Diagram 1}

--- Insert Diagram 1 here ---

The degree to which the benefit programs and indirect compensation areas intersect varies by country and by the extent to which governments use businesses to provide various forms of social protections to their populations. These are typically benefits that are contemplated by national legislatures as being in the best collective interest of society - health care, retirement, family and medical leave and paid time off.Countries may require organizations to offer these benefits to their full time employees and they may be supported or supplemented by government programs.

Perhaps the most critical aspect of the definition of benefits is that they are a form of indirect compensation. The concept of "indirect" suggests that these are things purchased for employees, but it also implies that these are forms of compensation that are not related to the production of products or the delivery of services, but are calculated independently of these outcomes. The implication is that commissions on sales, performance-based bonuses and executive incentives are forms of direct compensation, depending on how closely they are related to productivity. Of course, not all performance levels are measurable by purely quantifiable metrics, and so there is much that may fall into a grey area between the two. Similarly, casual clothing days, or flextime or telecommuting are things that are descriptive of job characteristics or working conditions, and are not actually forms of indirect compensation.

A second aspect of the indirect nature of benefits compensation, and the one most critical from a management perspective, is that it is not a direct incentive for improved performance, but that it engenders loyalty to the organization and a higher degree of job satisfaction which, in turn, inspires workers to perform better. These are things that may be descriptive of Herzberg's hygiene factors (1964), but may also have scalable impacts.

\subsection{A Management Definition}

From a management perspective, the critical aspect of compensation, job characteristics, or any other form of employee management, whether they are direct or indirect, is the effect they have on accomplishing organizational goals. Direct compensation is that which relates pay to performance, whether it is commission based or salaried and reviewed on a periodic basis. By contrast, discretionary benefits have an indirect effect on performance. They 
motivate employees to perform better principally because they inspire employee loyalty and job satisfaction. Benefits that are mandated by regulation create less organizational loyalty because, relative to discretionary benefits, they are less differentiated between organizations. Because of this, they are thought of as creating employee rights or entitlements (Weathington \& Tetrick, 2000, p. 155).

As the distinction between discretionary and non-discretionary programs is critical to understanding their motivational power, it may be useful to define them separately. Correspondingly, "discretionary benefits" are distinguished from "non-discretionary benefits" and the two categories of benefits may be described as:

Discretionary employee benefits are those organizational programs and practices that are not mandated by regulation or market forces, and that improve employee performance by increasing job satisfaction and/or organizational loyalty.

Non-discretionary employee benefits are those organizational programs and practices that are mandated by regulation or market forces, and that create an employee right, entitlement, or expectation.

These definitions are broader than those offered in the current literature in that they encompass the idea that, in addition to indirect forms of compensation, job characteristics or working conditions can also be forms of employee benefits. In this sense, upgraded office spaces, comfortable surroundings, casual dress codes, flextime options and the like may each be perceived by at least some employees to be desirable whether or not they represent a form of indirect compensation. As motivational tools, they are distinguishable from direct forms of compensation because they are related to the organization that is offering them rather than to the performance of some specific and immediate task.

Critical to these definitions is that the employee must perceive the programs and practices as things that are to his or her advantage, and they are benefits only to the extent that they are understood as such. Suppose, for example, an employee is offered participation in a $401 \mathrm{k}$ plan for which the employee's contributions would be matched in part by employer contributions. If the employee declines to participate in it, the program has not demonstrated its advantage to the employee, and participation in the "benefit" has less appeal to the employee than does the immediate direct compensation that non-participation in the program would yield.

Another important aspect of this definition is that job satisfaction and organizational loyalty are mediating variables between the benefits being offered by the employer and improved employee performance. When incentive-based direct compensation is offered, increased job satisfaction and organizational loyalty may be an outcome, but the employee's immediate motivation is to attain the incentive.

\section{Diagram 2}


By contrast, programs and practices that keep an organization in compliance with laws or regulations or are in place because of mimetic isomorphism are less helpful in creating distinctions that foster organizational loyalty, but they are not without their purposes and beneficial effects. Positive societal benefits stem from programs that support health care and retirement preparedness. These types of benefits may assist in inspiring professionalism, may foster a positive view of being attached to a particular industry or profession, or simply be a positive aspect of having full-time employment. Such programs also reinforce organizational citizenship and credibility.

\section{Diagram 3}

\section{--- Insert Diagram 3 here ---}

Non-discretionary benefits, such as employer contributions to Social Security, health care required by the Affordable Care Act, and time off required by the Family and Medical Leave Act may afford employees benefits that have positive social outcomes, but do not provide individual organizations with a competitive advantage in their compensation packages. Similarly, benefits that may be common within an industry, such as reimbursements for professional certifications or re-certifications, may be more thought of as attending to a professional status than to an association with the organization that is offering it.

\section{Conclusion}

Employee benefits have been the subject of much management study and analysis. To date, the term has been generally been defined in terms that are useful for accounting purposes with moderate variations in the specific terms depending on whether the definition is being used by government, management, or labor. For management, benefits have been long used to recruit and retain a talented workforce, and therein lies their utility. As employee perceptions of the value of benefits have been demonstrated to vary based on whether they are mandated by regulation or are discretionary on the part of the employer, their usefulness as a recruiting and retention tool is similarly dependent on this distinction. A conceptual managerial definition of employee benefits should derive from the utility of the benefits as recruiting and retention tools and relate to the form and direction of employee motivation they take.

\section{References}

Aron, C. (1999). Working at play: A history of vacations in the United States. New York: Oxford University Press.

Bishow, J. (2009). A look at supplemental pay: Overtime pay, bonuses, and shift differentials. Retrieved from: http://www.bls.gov/opub/mlr/cwc/a-look-at-supplemental-pay-overtime-pay-bonuses-and-shi ft-differentials.pdf

Blumenthal, D. (2006). Employer-sponsored health insurance in the United States: Origins 
and implications. The New England Journal of Medicine, 355(1), 82-88. doi:10.1056/NEJMhpr060703

Buchmueller, T.,\&Monheit, A. (2009).Employer-sponsored health insurance and the promise of health insurance reform.NBER Working Paper Number 14839. Cambridge, Mass.: National Bureau of Economic Research.

Bureau of Labor Statistics (2006).Benefits variables in the NLSY97.National Longitudinal Survey, No. 06-125.

Bureau of Labor Statistics (2008).Online Glossary. Available at: http://www.bls.gov/bls/glossary.htm\#B

Bureau of Labor Statistics (2015). National compensation survey: Employee benefits in the United States, March 2015. Retrieved from: http://www.bls.gov/ncs/ebs/benefits/2015/ebbl0057.pdf

Chan, K. C., Gee, M. V., \& Steiner, T. L. (2000). Employee happiness and corporate financial performance.Financial Practice \& Education, 10(2), 47-52.

Clark, R., Craig, L. \& Wilson, J. (2003).A history of public sector pensions in the United States. Philadelphia, PA: University of Pennsylvania Press.

Costa, D. (1998).The evolution of retirement: An American economic history, 1880 - 1990. Chicago, IL: Chicago University Press.

Employee Benefits (n.d.).In the business dictionary. Fairfax, VA: WebFinance, Inc. Retrieved from: http://www.businessdictionary.com/definition/employee-benefits.html

Employee Benefits (n.d.). In Black's law dictionary, $2^{\text {nd }}$ edition. TheLawDictionary.com. Retrieved from: http://thelawdictionary.org/employee-benefits/

Family and Medical Leave Act of 1993, 29 U.S.C. 2601 et seq. (1993), 29 C.F.R., Part 825.

Fringe Benefit (1947).In American college dictionary.New York, NY: Random House.

Fringe Benefit (2005). In American heritage new dictionary of cultural literacy, $3^{\text {rd }}$ edition, Boston, MA: Houghton Mifflin Company.

Ghosheh, N. (2013). Working conditions laws report 2012: A global review. International Labour Office, Geneva: ILO.

Ginneken, W. (2013).Civil society and the social protection floor.International Social Security Review, 66(3/4), 69-86. doi:10.1111/issr.12019

Hennock, E. (2007). The origin of the welfare state in England and Germany, 1850-1914: Social policies compared. Cambridge, UK: Cambridge University Press.

Herzberg, F. (1964).The motivation-hygiene concept and problems of manpower.Personnel Administration, 27(1), 3-7.

Holborn, H. (1969). A history of modern Germany - 1840-1945. Princeton, NJ: Princeton 


\section{MInstitute ${ }_{\text {Mnk }}^{\text {Macrothin }}$}

University Press.

Internal Revenue Service (2016).Publication 15-B Fringe benefits. Retrieved from: https://www.irs.gov/publications/p15b/ar02.html\#en_US_2016_publink1000193623

International Accounting Standard 19: Employee Benefits, retrieved from: http://eifrs.ifrs.org/eifrs/bnstandards/en/2015/ias19.pdf

International Labour Organization (2000).Maternity protection convention, 2000 (No. 183), Convention concerning the revision of the maternity protection convention (revised), 1952 (Entry into force: 07 Feb 2002) Adoption: Geneva, 88th ILC session (15 Jun 2000).

International Labour Organization (2012).R202 - Social Protection Floors Recommendation, Retrieved from: http://www.ilo.org/dyn/normlex/en/f?p=NORMLEXPUB:12100:0::NO:: P12100_INSTRUMENT_ID:3065524

International Labour Organization (2014).Maternity and paternity at work: Law and practice across the world. Geneva, Switzerland: ILO Publications.

Klonoski, R. (2015). Work benefits in America: A societal perspective. Lexington, KY: CreateSpace Publishing.

Leichter, H. (1979). A comparative approach to policy analysis: Health care policy in four nations. Cambridge, UK: Cambridge University Press. p. 121.ISBN 0-521-22648-1.

Lenhoff, D. (2004). Family and Medical Leave in the United States: Historical and Political Reflections, Conference Presentation: "After Birth: Policies for Healthy Women, Families and Workplaces"- A Conference and Signature Study of the Hubert H. Humphrey Institute of Public Affairs conducted in collaboration with the School of Public Health, University of Minnesota October 1, 2004.

Moran, P. (March 27, 2015). Retirement plans from around the world. Investopedia. Retrieved from: http://www.investopedia.com/financial-edge/0412/retirement-plans-from-around-the-world.as px

National Institute of Health (1798).Fifth Congress, Session 77. Retrieved from: http://history.nih.gov/research/downloads/1StatL605.pdf

National Labor Relations Act of 1935, Unfair Labor Practices, (Section 8 (a) (1)), as amended Oct. 22, 1951, ch. 534, § 1(b), 65 Stat. 601; Pub. L. 86-257, title II, § 201(e).

O'Brien, E. (2003). Employers' benefits from workers' health insurance.The Millbank Quarterly, 81(1), 5-43, doi: 10.1111/1468-0009.00037

Pension Act of 1862 (12 Stat. 566), enacted July 14, 1862.

Ralston, D. A. (1989). The benefits of Flextime: Real or imagined?. Journal of Organizational Behavior, 10(4), 369-373.

Rhine, S. W. (1987). The determinants of fringe benefits: Additional evidence. Journal of 


\section{Macrothink \\ International Journal of Human Resource Studies \\ ISSN 2162-3058 2016, Vol. 6, No. 2}

Risk \& Insurance, 54(4), 790-799.

Roosevelt Institute (n.d.). 1933: List of New Deal legislation. Retrieved from: http://rooseveltinstitute.org/policy-and-ideasroosevelt-historyfdr/new-deal

Rutigliano, A. J. (1986). Some would call it paternalism. Management Review, 75(7), 34-37.

Scofea, L. (1994). The development and growth of employer-provided health insurance.Monthly Labor Review, March, 1994.

Social Security Act (August 14, 1935) [H.R. 7260], Title II - Federal Old Age Benefits, Part 2 - Old Age Benefits, Sec. 202(d).

Society for Human Resource Management (2014).2014 Employee benefits: An overview of benefit offerings in the U.S.. Alexandria, VA: SHRM

Stabilization Act of 1942 (1942).Pub.L. 77-729, 56 Stat. 765, enacted October 2, 1942.

U.S. National Archives and Records Service (1974). Pamphlet describing M804: Revolutionary war pension and bounty-land-warrant application files. Washington, D.C.: National Archives and Record Service.

Weathington, B. L., \&Tetrick, L. E. (2000). Compensation or right: An analysis of employee "fringe" benefit perception. Employee Responsibilities \& Rights Journal, 12(3), 141-162. 


\section{Macrothink

Defining Employee Benefits: A Managerial Perspective

Diagrams:

\section{Diagram 1}

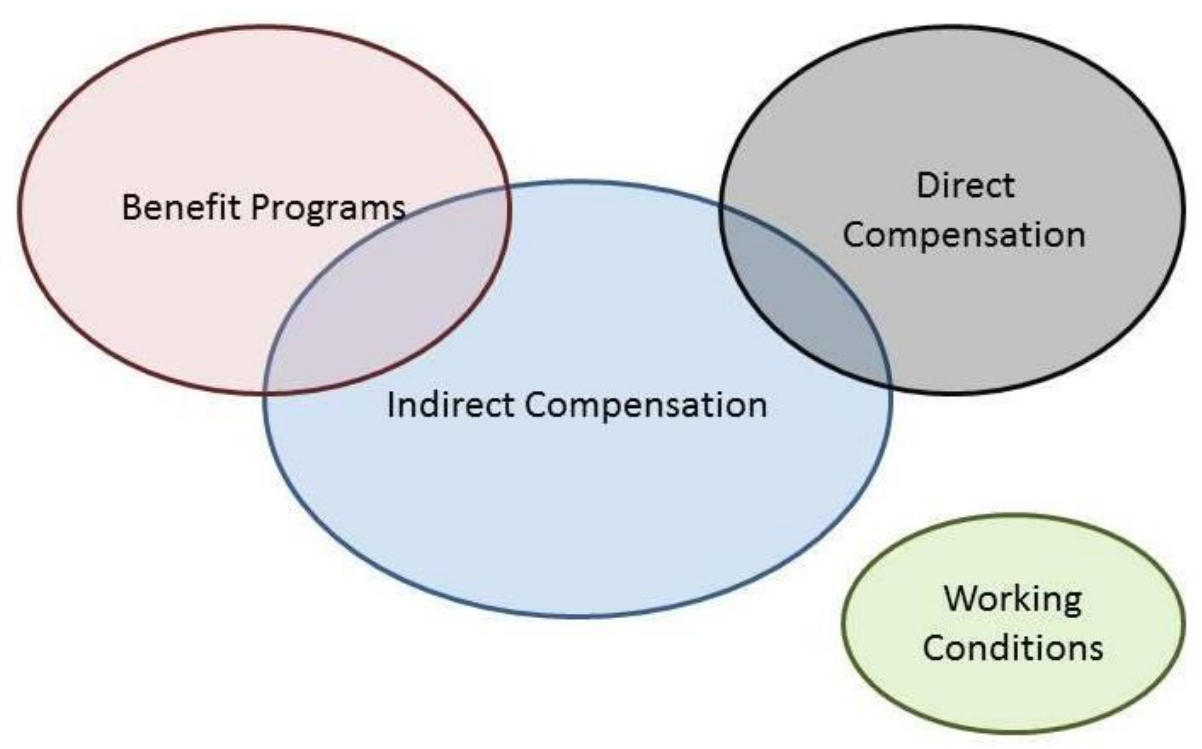

\section{Diagram 2}

Discretionary Employee Benefits:

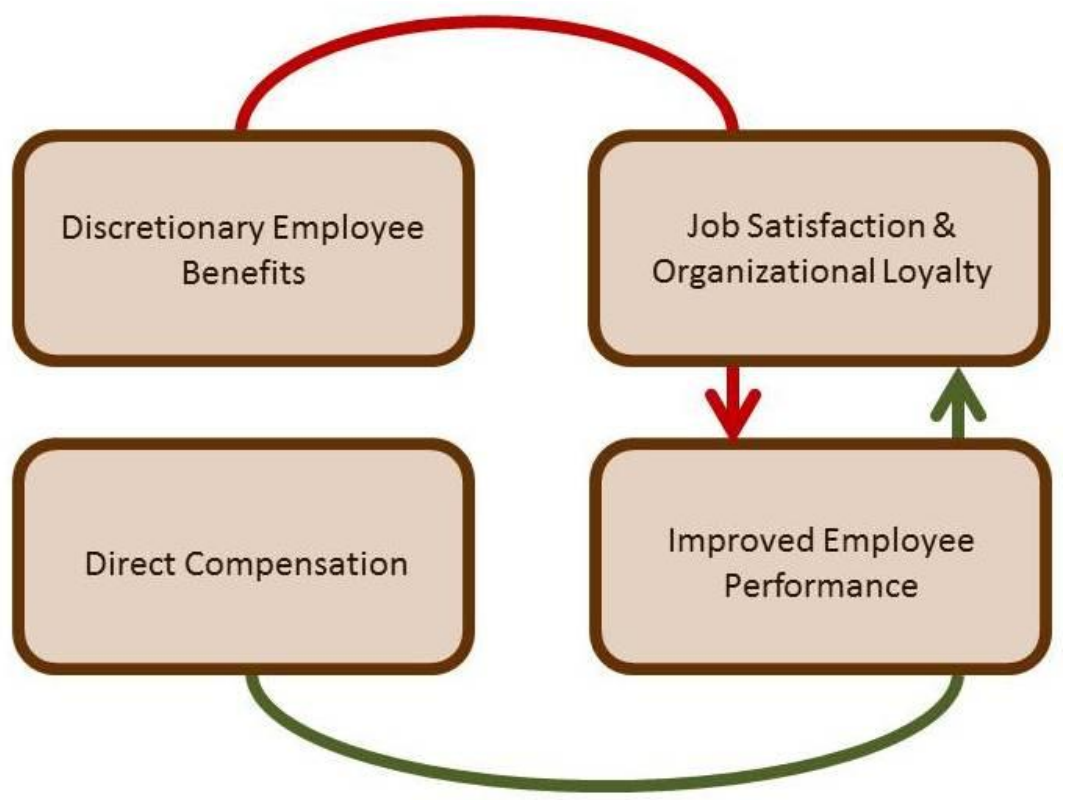




\section{Diagram 3}

Non-Discretionary Employee Benefits

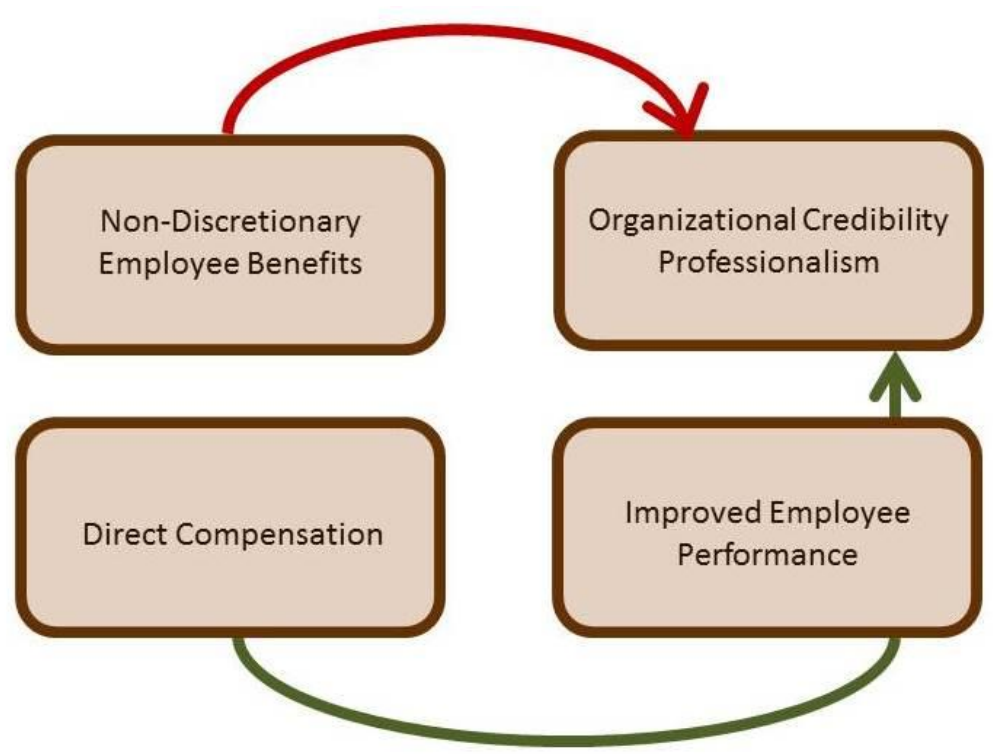




\section{Macrothink

Defining Employee Benefits: A Managerial Perspective

Tables

Table 1

A Summary of Selected Definitions of "Employee Benefits"

Source

Definition

Notes

\section{Government}

Bureau of Labor

Statistics

"nonwage compensation provided to employees"

National

Compensation

Survey

Internal

Revenue Service

"a form of pay for the performance of services"

"paid leave, supplementary pay, retirement, insurance and legally required benefits such as Social Security, Medicare, Federal and State unemployment insurance taxes, and workers' compensation"
Defined as compensation.

Defined by example. Payments made in addition to regular wages are considered "benefits."

\section{Popular}

American

College

Dictionary

(1947) "any of various benefits, as free life or health insurance, paid holidays, a pension, etc., received by an employee in addition to regular pay."
Broadly defined, this includes most forms of compensation that supplement wages and salaries. (Certain exclusions apply).
Defined by example. The list is limited to non-wage items and does not mention "supplemental pay." 
The American

Heritage ${ }^{\circledR}$ New

Dictionary of

Cultural

Literacy

\section{Business}

Business

Dictionary
"A payment to a worker in addition to salary or wages"

Defined as compensation.

"indirect and non-cash compensation paid to an employee"

"indirect, non-cash assistance given to an employee"
Defined as compensation not directly related to productivity.

Defined as assistance rather than compensation, suggesting that there may be a beneficial social purpose underlying the expense rather than something related to productivity. 
Table 2

Programs

Indirect Compensation Job Characteristics

Health Care Medical insurance Employer contributions

to medical insurance

Wellness programs

Employer sponsored wellness programs

Retirement Defined benefit plans

Savings

$\begin{array}{ll}\begin{array}{l}\text { Defined contribution } \\ \text { plans }\end{array} & \begin{array}{l}\text { Employer contributions } \\ \text { to defined contribution }\end{array} \\ & \text { plans }\end{array}$

Contributions to Social Employer contributions Security to Social Security

Financial \& Life insurance Compensation

Educational assistance

Educational assistance

bonuses*

Leave

Family and medical leave

leave

Time off

Paid time off 
Working

Flextime

Telecommuting
Employee

Programs

Professional

development

Housing \&

Relocation

Business

Travel
Free coffee

Employee discounts
Professional

membership fees

Temporary housing

Relocation assistance

Cab fare to an airport**

Car mileage

*Executive incentives that are tied to performance are more correctly classified as direct compensation than as a benefit. Holiday bonuses and other forms of payments not related to performance constitute benefits.

**Cab fare to an airport may be considered compensation to an employee to the extent it displaces the distance the employee would normally commute to work. Car mileage is a reimbursement for fuel, as well as wear and tear on a car owned by an individual; it is compensation to the extent it exceeds the actual expense incurred by the employee.

\section{Copyright Disclaimer}

Copyright for this article is retained by the author(s), with first publication rights granted to the journal.

This is an open-access article distributed under the terms and conditions of the Creative Commons Attribution license (http://creativecommons.org/licenses/by/3.0/). 